\title{
Delayed Epithelial Healing with Corneal Edema and Haze After Photorefractive Keratectomy Using Intraoperative Mitomycin C
}

\author{
Majid Moshirfar (D) ${ }^{1-3}$ \\ William B West J $r^{4}$ \\ Dallin C Milner ${ }^{5}$ \\ Shannon E McCabe (iD) \\ Yasmyne C Ronquillo (D) \\ Phillip C Hoopes (D) \\ 'Hoopes Vision Research Center, \\ Hoopes Vision, Draper, UT, 84020, USA; \\ ${ }^{2}$ John A. Moran Eye Center, Department \\ of Ophthalmology and Visual Sciences, \\ University of Utah School of Medicine, \\ Salt Lake City, UT, 84I32, USA; ${ }^{3}$ Utah \\ Lions Eye Bank, Murray, UT, 84I07, USA; \\ ${ }^{4}$ University of Utah School of Medicine, \\ Salt Lake City, UT, 84I32, USA; \\ ${ }^{5}$ University of Colorado School of \\ Medicine, Aurora, CO, 80045, USA
}

\begin{abstract}
We report an unusual presentation of presumed mitomycin $\mathrm{C}$ toxicity with possible subsequent hypersensitization to other medication toxicities. A 50-year-old female presented three months after photorefractive keratectomy with intraoperative mitomycin $\mathrm{C}$ for the management of persistent epithelial defects, corneal haze, and edema. She was found to have used an expansive and rapidly changing medical regimen which may have caused additional toxicity. These medications included besifloxacin, bromfenac, and ketotifen. Additives such as benzalkonium chloride and DuraSite ${ }^{\circledR}$ may have also contributed. Intraoperative mitomycin $\mathrm{C}$ can result in longstanding corneal haze, edema, and delayed epithelial healing in the setting of corneal refractive surgery. These may leave the cornea more susceptible to additional subsequent medication toxicities during the postoperative period. This report describes a case of mitomycin $\mathrm{C}$ exposure leading to a prolonged sensitivity to other medication toxicities, which has not been discussed elsewhere in the literature.
\end{abstract}

Keywords: polypharmacy, corneal toxicity, surface ablation, hypersensitivity, medication toxicity, mitomycin corneal toxicity, photorefractive keratectomy

\section{Introduction}

Polypharmacy, loosely defined as the concurrent use of multiple medications, has a well-studied negative impact on patient health. This has been demonstrated both systemically and specifically in ocular health; polypharmacy is associated with decreased patient compliance and increased adverse outcomes. ${ }^{1-3}$ Patients undergoing refractive surgery are especially at risk, as the cornea is more susceptible to insult and injury in the postoperative period. ${ }^{4,5}$ Even medications that are often used safely after photorefractive surgery can be toxic to the cornea if combined with one another under the wrong circumstances. In some cases, these medications may have synergistic toxicities, compromising wound healing and leading to unfavorable results. ${ }^{6}$ This can be particularly challenging when using medications whose toxic effects remain for extended periods of time. One of these medications is mitomycin $\mathrm{C}$ (MMC), which can cause corneal edema, delayed epithelial healing, and endothelial cell damage that persist for months after exposure to the medication. ${ }^{7-9} \mathrm{We}$ present a case of presumed topical polypharmacy centering around the intraoperative use of MMC and resulting in persistent corneal edema, endothelial cell loss, and delayed epithelial healing.
Correspondence: Majid Moshirfar

Tel $+|-80|-568-0200$

$\mathrm{Fax}+|-80|-563-0200$

Email cornea2020@me.com 


\section{Case Report}

A 50-year-old white woman was referred to our clinic three months after bilateral PRK for progressively worsening visual acuity, persistent epithelial defects, corneal edema, and sub-epithelial haze. The patient had undergone bilateral cataract surgery the year before. Prior to the PRK procedure, uncorrected distance visual acuity (UDVA) was $20 / 30$ OU. Manifest refraction was $-0.75+1.00 \times 100$ OD and $-0.25+0.75 \times 114$ OS. Epithelial debridement was performed with $20 \%$ alcohol for 20 seconds. The patient underwent excimer laser treatment using the VISX Star S4 laser (Johnson \& Johnson, Santa Ana, CA, USA) with an ablation zone of $6.5 \mathrm{~mm}$ and a $1 \mathrm{~mm}$ blend zone OU. One bottle of chilled balanced salt solution (BSS) was used to irrigate the eye immediately after ablation. Subsequently, mitomycin C $0.02 \%$ was applied for 12 seconds, followed by topical bromfenac $0.07 \%$ (Prolensa, Bausch + Lomb, Bridgewater, NJ, USA), moxifloxacin $0.5 \%$ (Vigamox, Novartis, Basel, Switzerland), prednisolone 1\% (Pred Forte, Allergan, Irvine, CA) and a bandage contact lens (BCL). The patient was then prescribed prednisolone and besifloxacin $0.6 \%$ (Besivance, Bausch + Lomb, Bridgewater, NJ, USA) drops four times daily as well as bromfenac $0.07 \%$ drops three times daily.

The patient's first postoperative examination was on the third day after surgery. UDVA was 20/100 OD and 20/60 OS with bilateral epithelial defects. BCLs were replaced and postoperative steroids, topical nonsteroidal antiinflammatory drugs (NSAIDs), and antibiotic drops were continued. On postoperative week one, she returned complaining of hazy vision. UDVA was 20/50 OD and 20/100+1 OS. Slit-lamp examination (SLE) revealed healing epithelial defects, mild stromal haze, and edema bilaterally. BCLs were removed and besifloxacin was discontinued. The patient was instructed to continue steroid and NSAID drops. At postoperative week two, UDVA had worsened to 20/80 OD and 20/400 OS. On slit-lamp examination, $2+$ superficial punctate keratitis (SPK) OD and 4+ SPK OS were observed along with increasing corneal haze and edema OU. Prednisolone drops were increased to eight times per day OU and bromfenac was continued.

Due to worsening visual acuity (20/80 OD and 20/400 OS), she sought a second opinion on postoperative day POD 14. Prednisolone and bromfenac were discontinued; punctal plugs and bilateral BCLs were placed for better management of the patient's SPK. Additionally, difluprednate (Durezol, Novartis, Basel, Switzerland) drops were started every six hours OU in the hopes of improving the corneal haze and were then tapered over six weeks. Artificial tears were encouraged. UDVA improved to 20/ 50 OD and 20/20 OS at the two-month postoperative visit with improved corneal haze and SPK. During this period, the patient was encouraged to use lifitegrast (Xiidra, Novartis, Basel, Switzerland), 20\% autologous blood serum (ABS), and artificial tears. Due to the patient's complaint of itching, ketotifen (Zaditor, Novartis, Basel, Switzerland) was started twice daily OU.

Two weeks later (two and a half months post-PRK), the patient returned to the clinic complaining of declining visual acuity to UDVA 20/80 OD and 20/40 OS. SLE revealed recurrence of bilateral corneal edema and diffuse haze, 2-3+ Descemet folds, and microcystic edema involving the epithelium. Due to concern for delayed post-PRK haze and inflammation, the patient was started on prednisolone every hour and bromfenac three times daily. Lifitegrast, ABS, and preservative-free artificial tears were continued. One week later, UDVA had worsened to 20/250 OD and 20/50 OS with an increase in Descemet folds and corneal edema OU. Intraocular pressure (IOP) was 18 OD and 19 OS. Bromfenac was discontinued, and prednisolone was replaced with hourly loteprednol (Lotemax, Bausch + Lomb, Bridgewater, NJ, USA). Brinzolamide-brimonidine tartrate (Simbrinza, Novartis, Basel, Switzerland) was started three times daily because of the concern for steroidinduced glaucoma. Visual acuity and ocular discomfort steadily worsened over the next ten days, at which time she was referred to our clinic for further evaluation.

At the time of referral, the patient complained of poor visual acuity and pain bilaterally but more severe in the right eye. UDVA was 20/500 OD and 20/60 OS. On SLE, corneal edema with 2-3+ Descemet folds was observed bilaterally (Figure 1A and B). An epithelial defect and 3+ SPK were also documented OD (Figure 1A). Bilateral BCLs were in place. Optical coherence tomography (OCT) demonstrated Descemet folds with stromal edema and hyperreflectivity of the anterior stroma OU (Figure 2A and B). On OCT, corneal thickness measured $723 \mu \mathrm{m}$ OD and $604 \mu \mathrm{m}$ OS. Accurate endothelial cell counts could not be obtained due to diffuse corneal swelling.

All current medications were discontinued except artificial tears. The patient was also started on doxycycline $100 \mathrm{mg}$ twice daily and vitamin C supplementation $1000 \mathrm{mg}$ daily. BCLs were left in place for an additional four weeks. During this time, moxifloxacin was chosen as a prophylactic measure as it is a preservative-free solution 


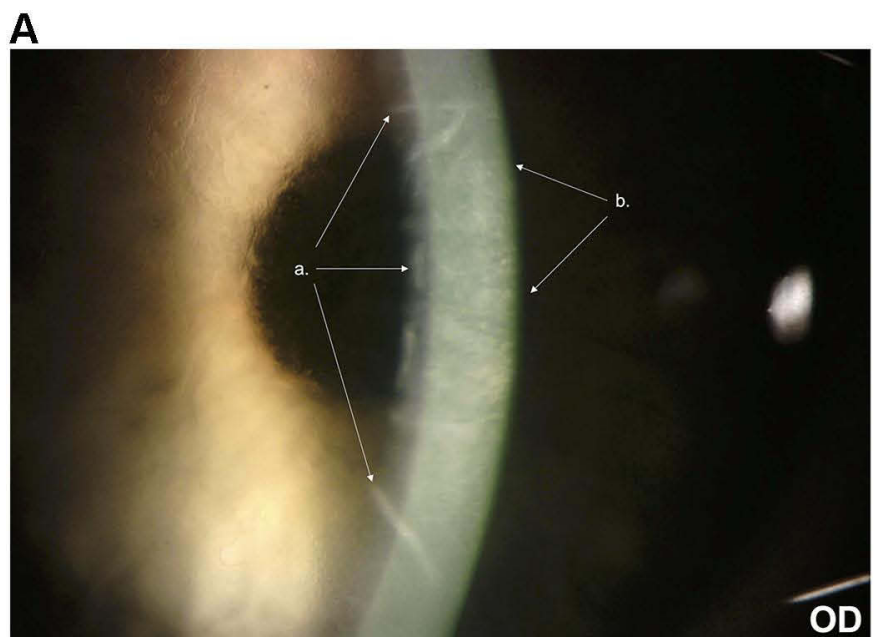

\section{B}

Figure I (A) Slit-lamp photograph OD 3 months post-PRK demonstrating Descemet folds (a) and corneal haze (b). (B) Slit-lamp photograph OS 3 months post-PRK demonstrating Descemet folds (a) and corneal haze (b).

A
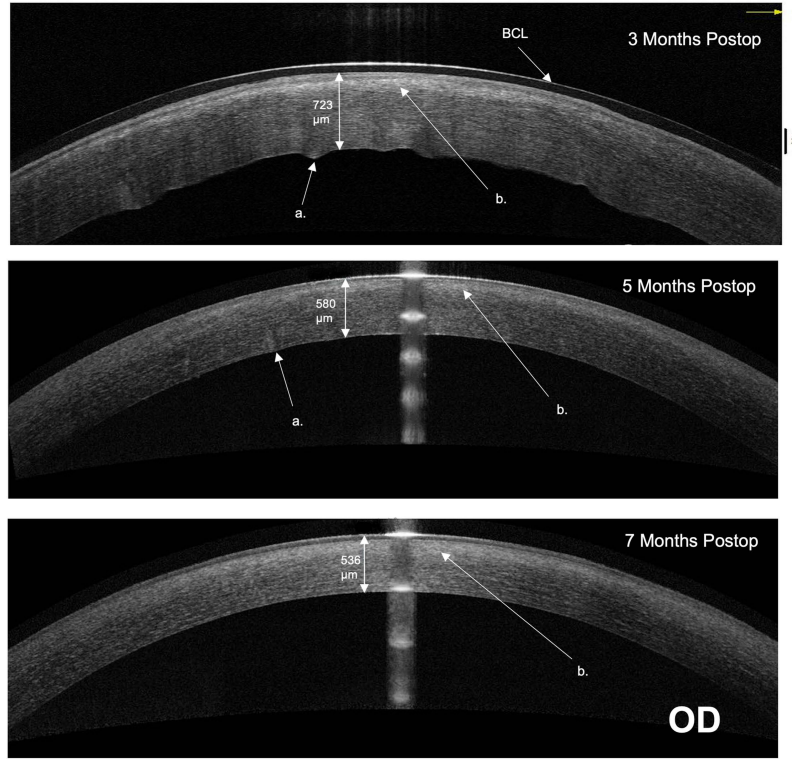

B
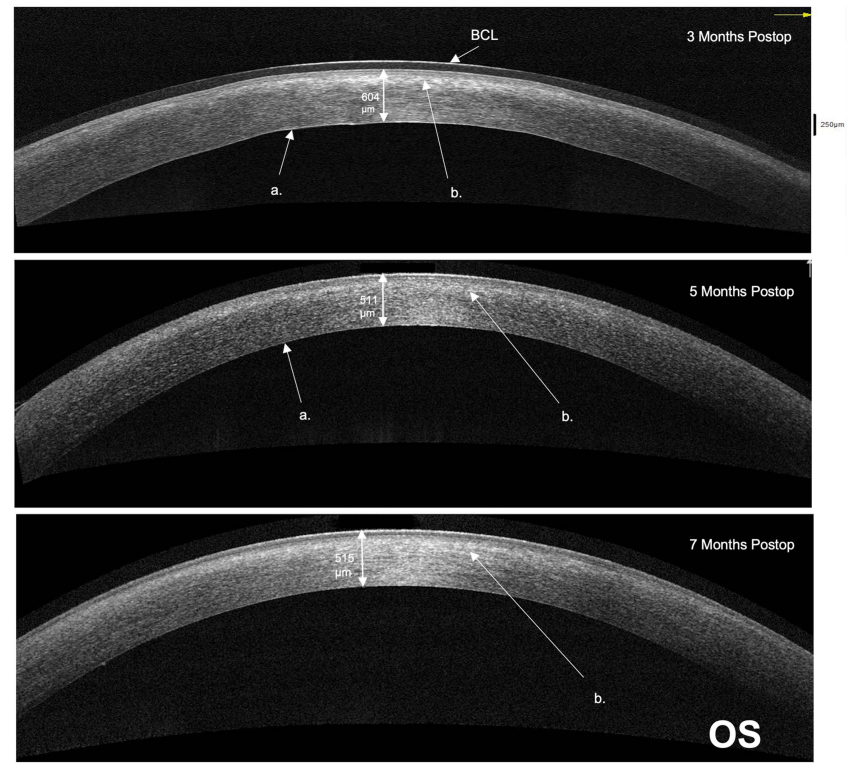

Figure 2 (A) AS-OCT OD progression over time. Corneal thicknesses are indicated. Descemet membrane folds (a) and anterior stromal edema (b) are indicated. (B) ASOCT OS progression over time. Corneal thicknesses are indicated. Descemet membrane folds (a) and anterior stromal edema (b) are indicated.

Abbreviation: $\mathrm{BCL}$, bandage contact lens.

and was used twice daily. Over the next several visits, UDVA improved to 20/50-3 OD and 20/20 OS. The epithelial defect, corneal edema, and Descemet folds all resolved. Corneal thickness improved from $591 \mu \mathrm{m}$ to 530 $\mu \mathrm{m} \mathrm{OD}$ and $541 \mu \mathrm{m}$ to $512 \mu \mathrm{m}$ OS (Figure 3). Endothelial cell counts were repeated at seven months post-PRK and demonstrated 564 cells $/ \mathrm{mm}^{2}$ OD and 864 cells $/ \mathrm{mm}^{2}$ OS (Figure 4). The patient was instructed to continue artificial tears, doxycycline, and vitamin $\mathrm{C}$.

\section{Discussion}

Given this patient's persistent corneal edema, recurrent epithelial defects, and endothelial cell loss, it appears that this patient was affected by a complex series of multiple overlapping drug toxicities. These symptoms may stem from initial MMC toxicity with resultant sensitization to other medication side effects. Additionally, the frequency of medication and dosing changes likely contributed to the adverse outcomes. ${ }^{1-3}$ 
Right / OD

Left / OS
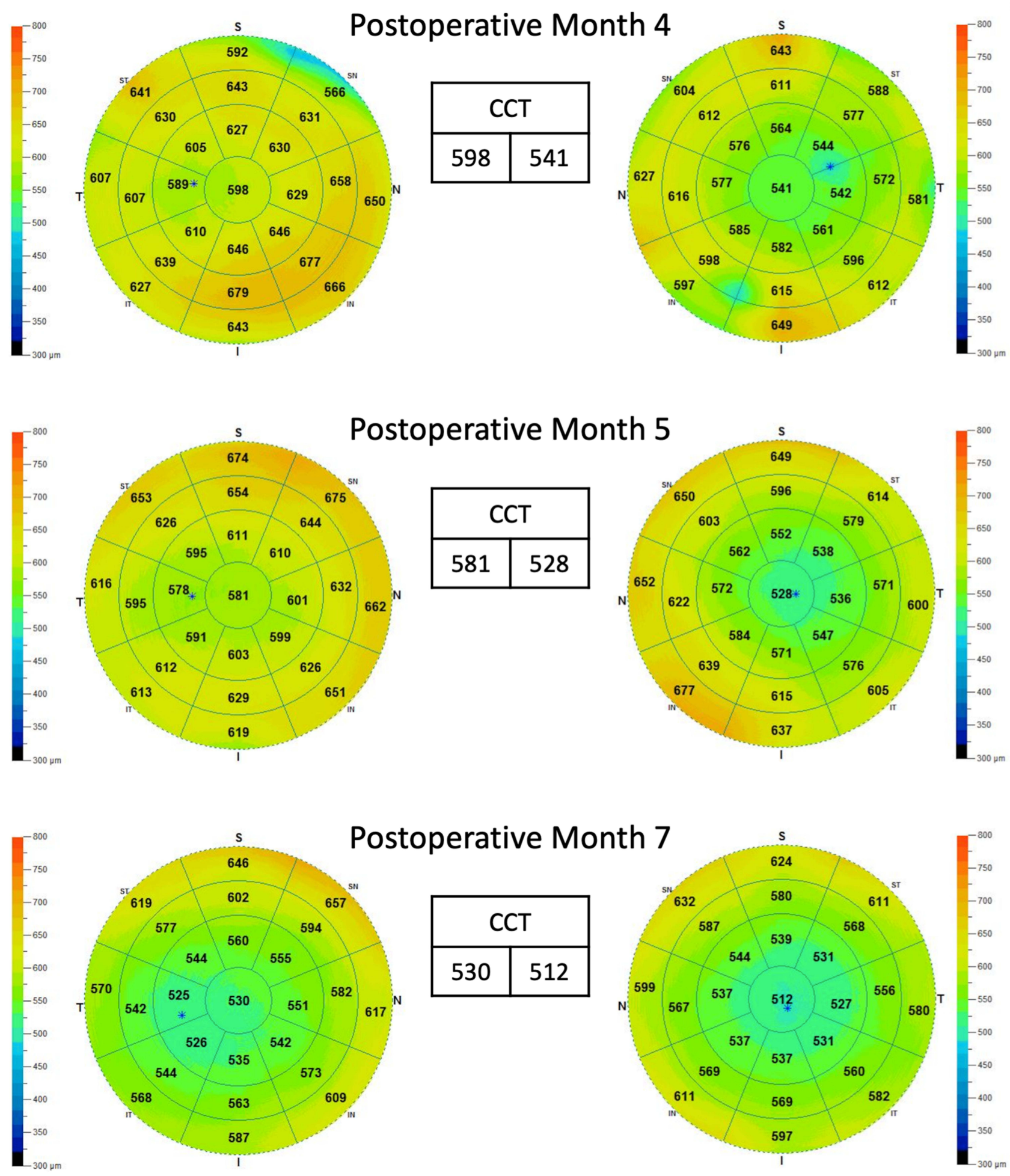

Figure 3 Pachymetry at 4 months post-PRK (top), 5 months post-PRK (middle), and 7 months post-PRK (bottom). Abbreviation: $\mathrm{CCT}$, central corneal thickness. 


\section{OD}

\section{Center}

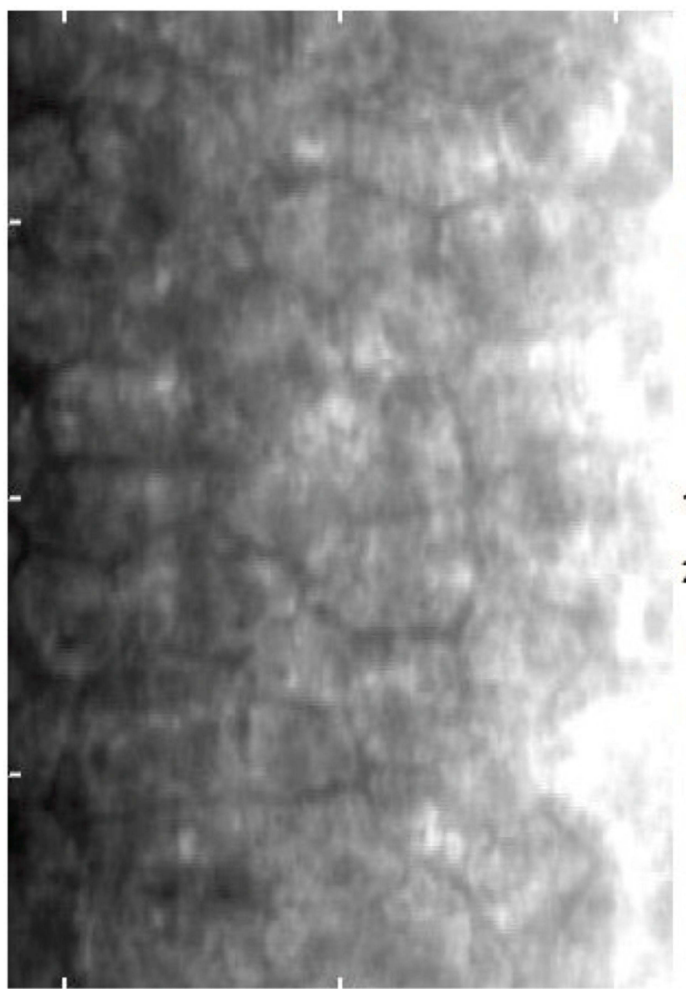

\section{Center}

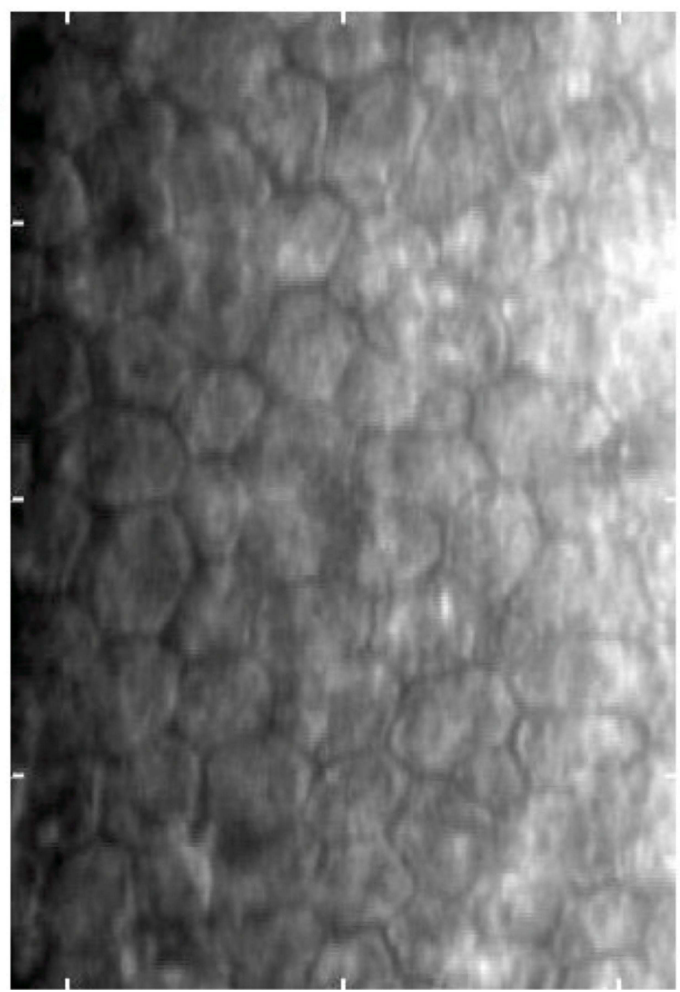

Figure 4 Specular endothelial cell density at 7 months postop.

The patient's complicated postoperative course likely started with intraoperative MMC use. MMC is commonly used to prevent corneal haze, a well-documented but uncommon risk of PRK. ${ }^{4}$ This postoperative haze is likely due to myofibroblast proliferation and subsequent collagen deposition within the corneal stroma and is more likely in the correction of high levels of myopia, previous corneal surgery, and increased ablation depth. ${ }^{10-13}$ Brief intraoperative use of MMC is generally safe and effective for reducing haze ${ }^{14}$ however, it is not free of risks. Potential adverse effects include corneal edema, decompensation, ulceration, and perforation. ${ }^{15}$ The edema, endothelial cell loss, and delayed epithelial healing seen in our patient are consistent with reports of mitomycin $\mathrm{C}$ toxicity in the literature. , $^{7,15,16}$ These adverse effects have been seen to last for months and are more common with increasing doses - especially when MMC is used topically over more than a few days. ${ }^{9,10}$ Because of these potential complications, many physicians recommend using the smallest possible doses to reduce side effects (often $0.02 \% \mathrm{MMC}$ for less than one minute). ${ }^{4} \mathrm{In}$ patients requiring only small visual corrections (less than five diopters), some suggest using no MMC at all since haze is unlikely to occur in this population. ${ }^{4,11,17,18}$ While our patient was only exposed to a routine dose of MMC, any use of MMC may have been unnecessary since the patient's correction of less than two diopters of spherical equivalent made haze development unlikely. Additionally, our patient's history of cataract surgery and recent PRK likely made the patient's corneas more susceptible to injury when MMC was introduced. ${ }^{19-22}$ Given the immediate and persistent corneal edema, delayed epithelial healing, and low endothelial cell counts, MMC toxicity was likely the initial cause of our patient's sequelae. One limitation of this report is the lack of data on endothelial cell count after cataract surgery before PRK. MMC's prolonged impact on the cornea may also have made the patient's corneas more vulnerable to future medication toxicities.

Bromfenac and other NSAIDs are often used for pain control after PRK without complications; however, there are reports of delayed epithelial healing, corneal edema, and corneal melt from these medications. ${ }^{23-25}$ Our patient's initial symptoms, substantial improvement after discontinuation of bromfenac, and recurrence when the medication was restarted all correlate with bromfenac 
toxicity. The relative rarity of NSAID toxicity, however, lends credence to the theory that initial damage from MMC may have sensitized these corneas to bromfenac's detrimental effects. It should also be noted that this patient was initially treated with bromfenac for two weeks, which is beyond the traditional use of up to three or four days following surface ablation. Adverse effects may also be more prevalent when medications are instilled beneath a bandage contact lens, as in our patient. ${ }^{23,24,26-29}$

Benzalkonium chloride (BAK), a preservative that is well known for its adverse effects on the cornea, may also have contributed to the patient's symptoms. These effects include corneal edema or degeneration, keratoconjunctivitis sicca, tear film dysfunction, and toxicity to both the corneal endothelium and epithelium. 5,30,31 These toxicities may occur at concentrations as low as $0.001 \%$ and can be cumulative over periods of prolonged use. ${ }^{5,32}$ Patients with damaged corneal epithelium are at especially high risk of complications from BAK. ${ }^{5}$ Our patient was using as many as five concurrent medications containing BAK consistently for nearly three months, totaling as many as 22 prescribed doses daily (steroids, NSAIDS, antibiotics, and anti-glaucoma medication). Several of these drugs had concentrations as high as $0.01 \%$ (well over the threshold of potential toxicity). The initial corneal edema and the patient's exacerbation at two and a half months also coincided with periods of higher BAK-containing medication use.
It is notable that the medications with higher concentrations of BAK, including ketotifen and besifloxacin, are independently associated with similar toxicities. ${ }^{5}$ Ketotifen, which contains a BAK concentration of $0.01 \%$, has long been associated with symptoms of ocular dryness and irritation. Interestingly, some studies now suggest that these symptoms may be a result of the BAK in the compound rather than a side effect of the medication itself. $^{33,34}$ Similarly, besifloxacin contains a $0.01 \%$ concentration of BAK and has been associated with ocular irritation and delayed epithelial healing. Besifloxacin additionally contains the carrier DuraSite ${ }^{\circledR}$, which is designed to prolong the medication's duration at the corneal surface. This maintains the concentrated BAK in contact with the corneal surface for a prolonged period, which may result in increased toxicity. ${ }^{35-37}$ The use of ketotifen and besifloxacin also coincides with our patient's worst symptoms.

Other factors that may be risk factors for the development of haze include chronic cigarette smoking, the use of nepafenac sodium, ciprofloxacin, ofloxacin, and corneal anesthetic abuse (Table 1).

\section{Conclusion}

Corneal edema, delayed epithelial healing, and endothelial cell toxicity are potential complications of intraoperative MMC usage that may last for months after surgery. If patients experience these symptoms, MMC

Table I Effect of Different Factors on Corneal Wound Healing After PRK

\begin{tabular}{|c|c|c|c|c|}
\hline Risk Factor & Study Type & Purpose & Effects & Reference \\
\hline $\begin{array}{l}\text { Mitomycin } \\
\mathrm{C} \text { (alcohol or blade } \\
\text { de-epithelialization) }\end{array}$ & $\begin{array}{l}\text { Animal Studies (adult } \\
\text { hens) } \\
\text { Control: no Mitomycin C }\end{array}$ & $\begin{array}{l}\text { Determine whether haze or epithelial } \\
\text { healing is affected by Mitomycin C }\end{array}$ & $\begin{array}{l}\text { Improvement in hen corneas } \\
\text { with MMC; delayed or no haze; } \\
\text { no difference in apoptosis }\end{array}$ & $\begin{array}{l}\text { Blanco- } \\
\text { Mezquita } \\
\text { et } \mathrm{al}^{37}\end{array}$ \\
\hline $\begin{array}{l}\text { Nepafenac sodium } \\
0.1 \% \text { (with } \\
\text { mitomycin C during } \\
\text { PRK) }\end{array}$ & $\begin{array}{l}\text { Retrospective } \\
\text { comparative ( } 69 \text { eyes) } \\
\text { nepafenac and Non- } \\
\text { nepafenac }\end{array}$ & $\begin{array}{l}\text { Assess delayed reepithelialization and } \\
\text { postop corneal haze }\end{array}$ & $\begin{array}{l}\text { No difference; no delay in } \\
\text { corneal epithelial healing; no } \\
\text { significant haze }\end{array}$ & Jalali et $\mathrm{al}^{38}$ \\
\hline $\begin{array}{l}\text { Ciprofloxacin, } \\
\text { ofloxacin }\end{array}$ & $\begin{array}{l}\text { Prospective study ( } 28 \\
\text { eyes) }\end{array}$ & $\begin{array}{l}\text { Determine corneal epithelial healing with } \\
\text { ciprofloxacin, ofloxacin, and ofloxacin with } \\
\text { artificial tears. }\end{array}$ & $\begin{array}{l}\text { Ciprofloxacin more prone to } \\
\text { impaired wound healing and } \\
\text { development of corneal haze }\end{array}$ & $\begin{array}{l}\text { G. Patel } \\
\text { et } \mathrm{al}^{39}\end{array}$ \\
\hline Topical Anesthetic & $\begin{array}{l}\text { Case report of delayed } \\
\text { epithelial healing after } \\
\text { PRK }\end{array}$ & Determine the Cause of delayed healing & $\begin{array}{l}\text { Delayed epithelial healing due to } \\
6 \text { month abuse of topical } \\
\text { anesthetics }\end{array}$ & $\begin{array}{l}\text { Ji Young Kim } \\
\text { et } \mathrm{al}^{40}\end{array}$ \\
\hline $\begin{array}{l}\text { Contact Lens } \\
\text { Wearing and } \\
\text { Chronic Cigarette } \\
\text { Smoking }\end{array}$ & $\begin{array}{l}\text { Prospective ( } 180 \text { eyes) } \\
\text { undergoing PRK }\end{array}$ & $\begin{array}{l}\text { Correlation of gender, Contact lens } \\
\text { wearing, chronic drinking, and chronic } \\
\text { smoking with wound healing after PRK }\end{array}$ & $\begin{array}{l}\text { Contact lens wearing and } \\
\text { cigarette smoking impair corneal } \\
\text { epithelial wound repair }\end{array}$ & $\begin{array}{l}\text { Anna } \\
\text { Roszkowska } \\
\text { et } \mathrm{al}^{41}\end{array}$ \\
\hline
\end{tabular}


may be considered a potential cause even weeks or months after exposure. MMC may even sensitize the cornea to other medication toxicities. It appears prudent to be particularly cautious in these cases about the addition of other topical medications, especially those with potential corneal toxicities such as bromfenac, besifloxacin, or ketotifen. If multiple medications are used, it is also important to account for potentially toxic preservatives or binding agents like BAK and DuraSite ${ }^{\circledR}$. While additives are generally safe in isolated medications, their ubiquitous use may result in unforeseen adverse effects. Clinicians should be mindful of synergistic toxicities when using multiple topical medications simultaneously, especially in patients with already compromised corneas.

\section{Ethics Approval}

This case report has been approved by the Hoopes Vision Ethics Board. The study conforms with the Helsinki Declaration of 1964, as revised in 2013, concerning human and animal rights.

\section{Consent for Publication}

The patient signed an informed consent for publication and use of data in research. No information was included in the report that could result in the identification of the patient.

\section{Disclosure}

The authors report no conflicts of interest in this work.

\section{References}

1. Jyrkkä J, Enlund H, Korhonen MJ, Sulkava R, Hartikainen S Polypharmacy status as an indicator of mortality in an elderly population. Drugs Aging. 2009;26(12):1039-1048. doi:10.2165/ 11319530-000000000-00000

2. Parsons C, Lapane K, Kerse N, Hughes C. Prescribing for older people in nursing homes: a review of the key issues. Int J Older People Nurs. 2011;6(1):45-54. doi:10.1111/j.1748-3743.2010.00264.x

3. Robin A, Grover D. Compliance and adherence in glaucoma management. Indian J Ophthalmol. 2011;59:93. doi:10.4103/03014738.73693

4. Netto MV, Mohan RR, Sinha S, Sharma A, Gupta PC, Wilson SE. Effect of prophylactic and therapeutic mitomycin $\mathrm{C}$ on corneal apoptosis, cellular proliferation, haze, and long-term keratocyte density in rabbits. J Refract Surg. 2006;22(6):562-574. doi:10.3928/1081-597X20060601-08

5. Rosin LM, Bell NP. Preservative toxicity in glaucoma medication: clinical evaluation of benzalkonium chloride-free $0.5 \%$ timolol eye drops. Clin Ophthalmol. 2013;7:2131-2135. doi:10.2147/OPTH. S41358

6. Rath A, Eichhorn M, Träger K, Paulsen F, Hampel U. In vitro effects of benzalkonium chloride and prostaglandins on human meibomian gland epithelial cells. Ann Anat. 2019;222:129-138. doi:10.1016/j. aanat.2018.12.003
7. Kremer I, Ehrenberg M, Levinger S. Delayed epithelial healing following photorefractive keratectomy with mitomycin $\mathrm{C}$ treatment. Acta Ophthalmol. 2012;90(3):271-276. doi:10.1111/j.17553768.2010.01894.x

8. Lee DH, Chung HS, Jeon YC, Boo SD, Yoon YD, Kim JG. Photorefractive keratectomy with intraoperative mitomycin-C application. J Cataract Refract Surg. 2005;31(12):2293-2298. doi:10.1016/j.jcrs.2005.05.027

9. Nassiri N, Farahangiz S, Rahnavardi M, Rahmani L, Nassiri N. Corneal endothelial cell injury induced by mitomycin-C in photorefractive keratectomy: nonrandomized controlled trial. J Cataract Refract Surg. 2008;34(6):902-908. doi:10.1016/j.jcrs.2008.03.007

10. Dos Santos Forseto A, Marques JC, Nosé W. Photorefractive keratectomy with mitomycin $\mathrm{C}$ after penetrating and lamellar keratoplasty. Cornea. 2010;29(10):1103-1108. doi:10.1097/ ICO.0b013e3181d0fecd

11. Møller-Pedersen T, Cavanagh HD, Petroll WM, Jester JV. Corneal haze development after PRK is regulated by volume of stromal tissue removal. Cornea. 1998;17(6):627-639. doi:10.1097/00003226199811000-00011

12. Kremer I, Kaplan A, Novikov I, Blumenthal M. Patterns of late corneal scarring after photorefractive keratectomy in high and severe myopia. Ophthalmology. 1999;106(3):467-473. doi:10.1016/S01616420(99)90104-5

13. Jester JV, Ho-Chang J. Modulation of cultured corneal keratocyte phenotype by growth factors/cytokines control in vitro contractility and extracellular matrix contraction. Exp Eye Res. 2003;77 (5):581-592. doi:10.1016/S0014-4835(03)00188-X

14. Leccisotti A. Mitomycin $\mathrm{C}$ in photorefractive keratectomy: effect on epithelialization and predictability. Cornea. 2008;27(3):288-291. doi:10.1097/ICO.0b013e31815c5a51

15. Pfister RR. Permanent corneal edema resulting from the treatment of PTK corneal haze with mitomycin: a case report. Cornea. 2004;23 (7):744-747. doi:10.1097/01.icuo.0000126328.92475.cf

16. Rubinfeld RS, Pfister RR, Stein RM, et al. Serious complications of topical Mitomycin-C after pterygium surgery. Ophthalmology. 1992;99(11):1647-1654. doi:10.1016/S0161-6420(92)31749-X

17. Song JS, Kim JH, Yang M, Sul D, Kim HM. Mitomycin-C concentration in cornea and aqueous humor and apoptosis in the stroma after topical mitomycin-C application: effects of mitomycin-C application time and concentration. Cornea. 2007;26(4):461-467. doi:10.1097/ ICO.0b013e $318030 \mathrm{~d} 217$

18. Bourne WM, Nelson LR, Hodge DO. Continued endothelial cell loss ten years after lens implantation. Ophthalmology. 1994;101 (6):1014-1023. doi:10.1016/S0161-6420(94)31224-3

19. Patel SV, Bourne WM. Corneal endothelial cell loss 9 years after excimer laser keratorefractive surgery. Arch Ophthalmol. 2009;127 (11):1423-1427. doi:10.1001/archophthalmol.2009.192

20. Kim K-S, Jeon S-J, Edelhauser HF. Corneal endothelial morphology and barrier function following excimer laser photorefractive keratectomy. In: Advances in Corneal Research. Springer US;1997:329-342. doi:10.1007/978-1-4615-5389-2_32

21. Galgauskas S, Norvydaite D, Krasauskaite D, Stech S, Ašoklis RS. Agerelated changes in corneal thickness and endothelial characteristics. Clin Interv Aging. 2013;8:1445-1450. doi:10.2147/CIA.S51693

22. Golan O, Randleman JB. Pain management after photorefractive keratectomy. Curr Opin Ophthalmol. 2018;29(4):306-312. doi:10.1097/ICU.0000000000000486

23. Asai T, Nakagami T, Mochizuki M, Hata N, Tsuchiya T, Hotta Y. Three cases of corneal melting after instillation of a new nonsteroidal anti-inflammatory drug. Cornea. 2006;25(2):224-227. doi:10.1097/ 01.ico.0000177835.93130.d4

24. Durrie DS, Kennard MG, Boghossian AJ. Effects of nonsteroidal ophthalmic drops on epithelial healing and pain in patients undergoing bilateral photorefractive keratectomy (PRK). Adv Ther. 2007;24(6):1278-1285. doi:10.1007/BF02877774 
25. Faktorovich EG, Melwani K. Efficacy and safety of pain relief medications after photorefractive keratectomy: review of prospective randomized trials. J Cataract Refract Surg. 2014;40(10):1716-1730. doi:10.1016/j.jcrs.2014.08.001

26. Trattler W, McDonald M. Double-masked comparison of ketorolac tromethamine $0.4 \%$ versus nepafenac sodium $0.1 \%$ for postoperative healing rates and pain control in eyes undergoing surface ablation. Cornea. 2007;26(6):665-669. doi:10.1097/ICO.0b013e31805290ce

27. Margulis AV, Houben E, Hallas J, et al. Ophthalmic nepafenac use in the Netherlands and Denmark. Acta Ophthalmol. 2017;95 (5):509-517. doi:10.1111/aos.13468

28. Prasher P. Acute corneal melt associated with topical bromfenac use. Eye Contact Lens. 2012;38(4):260-262. doi:10.1097/ ICL.0b013e318235c506

29. Ayaki M, Noda Y, Yaguchi S, et al. Cytotoxicity of antiglaucoma ophthalmic solutions for human corneal endothelial cells. Nihon Ganka Gakkai Zasshi. 2009;113(5):576-582.

30. Ramli N, Supramaniam G, Samsudin A, Juana A, Zahari M, Choo MM. Ocular surface disease in glaucoma. Optom Vis Sci. 2015;92(9):e222-e226. doi:10.1097/OPX.0000000000000542

31. Cha SH, Lee JS, Oum BS, Kim CD. Corneal epithelial cellular dysfunction from benzalkonium chloride (BAC) in vitro. Clin Exp Ophthalmol. 2004;32(2):180-184. doi:10.1111/j.14429071.2004.00782.x

32. Pauly A, Brasnu E, Riancho L, Brignole-Baudouin F, Baudouin C. Multiple endpoint analysis of BAC-preserved and unpreserved antiallergic eye drops on a 3D-reconstituted corneal epithelial model. Mol Vis. 2011;17:745-755.

33. Boboridis KG, Kozeis N, Konstas AGP. Revisiting ocular allergy: evaluating symptoms, benzalkonium chloride and efficacy of topical Ketotifen 0.025\%. Ocul Immunol Inflamm. 2020;28(2):188-190. doi:10.1080/09273948.2018.1560478
34. McLean S, Sheikh A. Effectiveness, tolerability and safety of azithromycin $1 \%$ in DuraSite ${ }^{\circledR}$ for acute bacterial conjunctivitis. Patient Prefer Adherence. 2010;4:69-76. doi:10.2147/ppa.s4203

35. Talamo JH, Hatch KM, Woodcock EC. Delayed epithelial closure after PRK associated with topical besifloxacin use. Cornea. 2013;32 (10):1365-1368. doi:10.1097/ICO.0b013e31829e1e8c

36. Granet D, Lichtenstein SJ, Onofrey B, Katz JA. An assessment of the tolerability of moxifloxacin $0.5 \%$ compared to azithromycin $1.0 \%$ in DuraSite. Clin Ophthalmol. 2007;1(4):519-525.

37. Blanco-Mezquita T, Espandar L, Torres R, et al. Does mitomycin C cause toxicity in the cornea after photorefractive keratectomy? A comparative wound-healing study in a refractive surgery animal model. Cornea. 2014;33(11):1225-1231. doi:10.1097/ ICO.0000000000000219

38. Jalali S, Yuen LH, Boxer Wachler BS. Effect of nepafenac sodium $0.1 \%$ on delayed corneal epithelial healing and haze after photorefractive keratectomy. Retrospective comparative study. J Cataract Refract Surg. 2008;34:1542-1545. doi:10.1016/j.jcrs.2008.04.036

39. Patel GM, Chuang AZ, Kiang E, Ramesh N, Mitra S, Yee RW. Epithelial healing rates with topical ciprofloxacin, ofloxacin, and ofloxacin with artificial tears after photorefractive keratectomy. $J$ Cataract Refract Surg. 2000;26:690-694. doi:10.1016/S08863350(00)00411-9

40. Kim JY, Choi YS, Lee JH. Keratitis from corneal anesthetic abuse after photorefractive keratectomy. $J$ Cataract Refract Surg. 1997;23:447-449. doi:10.1016/s0886-3350(97)80192-7

41. Roszkowska AM, De Grazia L, Visalli M, et al. Contact lens wearing and chronic cigarette smoking positively correlate with TGF- $\beta 1$ and VEGF tear levels and impaired corneal wound healing after photorefractive keratectomy. Curr Eye Res. 2013;38(3):335-341. doi: $10.3109 / 02713683.2012 .745880$
International Medical Case Reports Journal

\section{Publish your work in this journal}

The International Medical Case Reports Journal is an international, peer-reviewed open-access journal publishing original case reports from all medical specialties. Previously unpublished medical posters are also accepted relating to any area of clinical or preclinical science. Submissions should not normally exceed 2,000 words or 4

\section{Dovepress}

published pages including figures, diagrams and references. The manuscript management system is completely online and includes a very quick and fair peer-review system, which is all easy to use. Visit http://www.dovepress.com/testimonials.php to read real quotes from published authors. 